\title{
THE IMPLEMENTATION OF ENHANCING MALE PARTICIPATION ON FAMILY PLANNING POLICY IN BANDUNG BARAT REGENCY
}

\author{
*Dadang Suhenda, **Evalina Franciska Hutasoit \\ * National Population and Family Planning Board (BKKBN) West Java, Indonesia \\ ** National Population and Family Planning Board (BKKBN) West Java, Indonesia
}

Email :dadang.jagoan@gmail.com

\begin{abstract}
This study aims to analyze the conduct implementation of the increasing male contraception policy in Bandung Barat Regency. The study is using qualitative methods with case studies approachment. Qualitative data were gained from 16 informants which consist of implementor group as program managers, and partnership and community group as the targeted group. This study was conducted at three locations: district of Cililin, Batu Jajar, and Parongpong. The study shows that the decision process to decide PPM as the standard and goals of the family planning program has been understood by all of its administrators and resources available for this program has been considered as sufficient in terms of quantity but yet still lack in quality. Furthermore, communication and coordination processes among administrators and associates are shown to be in accordance with the operational procedures, hence, influencing characteristics of the family planning programs. It is found that religion consideration makes the residents refuse male contraception. Family planning programs are considered as women's business for some certain people. Fortunately, the existence of a spirit of militancy, high loyalty and disposition/attitude possessed by the management officers towards this male family planning program has a major influence on the success of the program. Moreover, the study shows that politicians have demonstrated strong support for the family planning program. This supports take places through budgeting and politician's active participation in the male contraceptive programs.
\end{abstract}

Keywords: Male participation, family planning programs, policy implementation.

Abstrak. Penelitian ini bertujuan untuk menganalisis faktor-faktor yang memengaruhi kinerja pencapaian kebijakan KB pria di Kabupaten Bandung Barat. Metode dalam penelitian ini adalah metode kualitatif dengan menggunakan pendekatan studi kasus. Berdasarkan hasil penelitian, dapat diketahui bahwa proses penetapan PPM sebagai standar dan tujuan kebijakan KB telah dipahami oleh seluruh pengelola KB dan jumlah ketersedian sumber daya saat ini sudah dianggap mencukupi dari segi jumlah namun masih kurang dari segi kualitas. Selain itu diketahui juga bahwa proses komunikasi dan koordinasi antar pengelola maupun dengan mitra kerja telah dilakukan sesuai dengan mekanisme operasional dan hal ini memengaruhi karakteristik pengelola KB. Dari segi faktor sosial budaya diketahui bahwa masyarakat banyak yang menolak program KB pria dengan alasan agama. Sebagian ada yang menganggap bahwa KB hanya untuk urusan wanita. Namun adanya jiwa militansi, loyalitas tinggi dan disposisi/sikap yang dimiliki oleh petugas pengelola terhadap program KB pria ini berpengaruh besar terhadap keberhasilan program. Selain itu juga diketahui bahwa dukungan elit politik terhadap program KB sudah sangat baik dari segi penganggaran maupun keterlibatannya secara aktif dalam Kebijakan KB Pria.

Kata kunci: KB pria, program KB, Implementasi Kebijakan

\section{INTRODUCTION}

To date, the male contraceptive programs have been widely studied, whether in term of factors that affect participation (Musafaah, 2012; Ernawati, 2016; Desmalita, Nursal, \& Suryati, 2009; Kassa, Abajobir, \& Gedefaw. 2014). male participation on contraceptive pr 20 uhatiah, 2012), and thi iily planning (7
Putriandani, 2015; Taufik \& Salawati, 2015 dan Setyaningsih, 2007).

Increased male participation in family planning program is as important as women's participation. However, studies about the implementation of the male contraceptive program remain rarely found. According 
to Zaeni (2006), there are several factors influencing the lack of male participation on the family planning program such as lack of resources, family planning officer's low-ability to counsel, hence the lack of disposition and the organizational structure uncertainty. In addition, the policy contexts such as religious figure, the culture of the submissive and compliant role of women, and the lack of promotive media for men also affect the implementation of the family planning program. This study aims to analyze the implementation of increasing male contraception policy in Bandung Barat regency, as well as analyzing influencing factors related to the implementation.

On the other hand, Wudi Amini (2011) proposes that there are three main factors supporting the success of male contraception (vasectomy) in Situbondo: firstly, implementor disposition (i.e commitment, honesty, democracy and the understanding of policy implementation), secondly, the characteristics of policy acting board, and thirdly, the active public-participation and other environmental factors (i.e socioeconomics, culture, and political alignment).

According to the result of male participation evaluation in West Java in 2014, there are several districts/municipals for instance: Bandung Barat District that exceed the average participation of male contraception (2\%). The Bandung Barat government shows prominent political support for population and family planning program by a regional regulation No.2 Tahun 2013 of the management of the district family planning policy. The regulation further mentioned the need for increasing male contraception participation.

\section{Theoretical Review}

The conceptual model used in the study refers to the implementation models policy of Van Meter-Van Horn as seen in Figure 1.

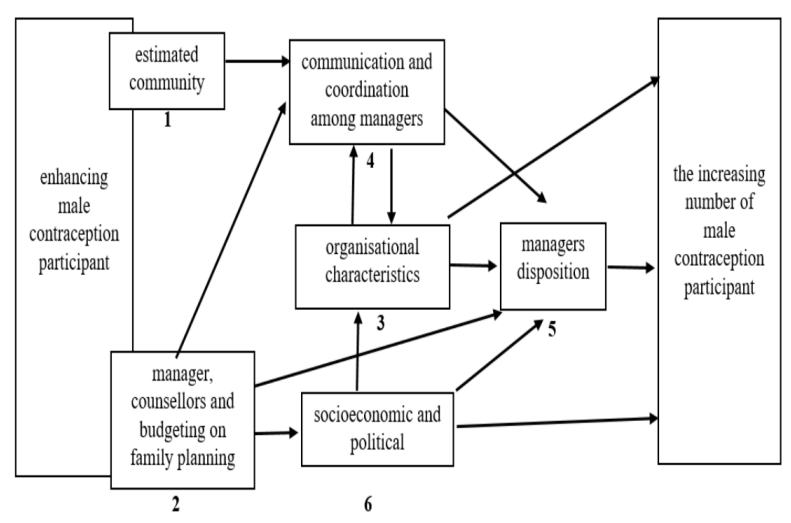

Figure 1. Conceptual Model.

The model explains that the success in implementing a program to increase male family planning participation in Bandung Barat Regency is strongly influenced by several factors, including:

1. Standards and objectives of implementing a male family planning program are based on the ratio of male participation to estimated community demand which aims to the increase of male contraception.

2. The existence of family planning counselors is related to the number, distribution and competence and funding of contraception for male.

3. The characteristics of the family planning organization in Bandung Barat Regency consist of organizational structure, work culture within the organization, and coordination among the program administrator.

4. Communication among program administrators, coordination between administrators and interrelated agency are important. Coordinating health service with health officer agency, coordinating budget with national population and family planning board and the national health insurance, and also mass mobilization coordination with male contraception groups, religious groups, and the national army.

5. The administrator's disposition consists of response, cognition and the preference of value regarding the policy of male contraception.

6. Socioeconomic and political background in Bandung Barat Regency.

Using the conceptual model above, the researcher aims to discover information and input regarding factors affecting the success of the male contraception program. Moreover, data produced will be used to solve the obstacle of male contraception program, hence enhance male contraception participant.

\section{METHODS}

The study was conducted using qualitative and quantitative methods in case studies and descriptive methods. Data collection were performed in three months from January to March 2016. The collected data consist of observational data, interviews with key informants, and document review. The research subject being examined is specific, therefore, the author choose and use three locations as samples, which are the district of Cililin, Batu Jajar, and Parongpong. Informants were selected using purposive sampling technique with the next key informants were gained based on recommendation of the previous informant (snowball) as long as the informants fulfill the required criteria in terms of capacity as the program managers, participate in the male contraception programs and mastering the 
male contraception matter in Bandung Barat Regency. As much as sixteen informants were interviewed consist of implementor groups such as family planning program managers, partnership group and male contraceptive community group were interviewed.

The implementation of increasing male contraception policy in the three districts above is analyzed descriptively, and the result is expected to picture the program implementation for the entire Bandung Barat Regency.

\section{RESULTS AND DISSCUSION}

\section{The male contraception program's standard and aim}

According to Van Meter and Van Horn (1975), the success of implementing a policy is measurable by the size and the sociocultural objectives of the policy at the level of policy implementers. Studies show that policy implementation requires identifiable and measurable goals and objectives. This is because the implementation cannot be categorized as succeed or fail without the purpose of assessing its implementation, (Pressman and Wildavsky, 1973 in Van Meter and Van Horn,1975). Therefore, policy performance is a basic assessment of the achievement level for standards and targets.

The standards and objectives in implementing a male contraception program are based on the estimated community demand (PPM) for male participants. The aim is to increase male participation in the family planning program. The study obtains several data related to standards and goals of the male contraception from key informants in three sample districts: Cililin, Batu Jajar, and Parongpong. The ratio of the new user of male contraception in table 1 .

Table 1. The ratio of male contraception's new user to estimated community demand in 2015 .

\begin{tabular}{|c|c|c|c|c|c|c|}
\hline \multirow{2}{*}{ District } & \multicolumn{2}{|c|}{$\begin{array}{c}\text { Number of the user } \\
\text { (estimated community } \\
\text { demand) }\end{array}$} & \multicolumn{2}{|c|}{ Number of new users } & \multicolumn{2}{c|}{ Percentage (\%) } \\
\cline { 2 - 7 } & Condom & vasectomy & Condom & vasectomy & Condom & vasectomy \\
\hline Cililin & 65 & 50 & 64 & 22 & $98,5 \%$ & $44,0 \%$ \\
\hline Batu Jajar & 89 & 50 & 57 & 39 & $64,0 \%$ & $78,0 \%$ \\
\hline Parongpong & 87 & 50 & 15 & 0 & $17,2 \%$ & $0,0 \%$ \\
\hline
\end{tabular}

According to routine statistics in 2015 , it is found that there are 3.425 condom users and 2.737 vasectomy participants out of 331.139 couple of fertile age. Table 1 shows that the lowest percentage of a new user for male contraception can be found in Parongpong (17,2\% and no vasectomy new user). District Cililin shows the highest new user of condoms $(98,5 \%)$ while Batu Jajar shows the highest new user of vasectomy $(78 \%)$.
Data analysis from three districts shows that the current process determining male PPM standard is in accordance with the unmet need resulted from previous family data collection. Observations further confirm that family planning managers have conducted data collection and couples of fertile age mapping using the existing standard format. Moreover, PPM data in each working area has been clearly displayed in the UPT KB office.

Interviews with key informants show that PPM calculation is considered as fair, realistic, and measurable, and, therefore the PPM is achievable. In addition, staff meeting or other meetings related to male contraception programs enhance coordination and communication among the interrelated sector.

" the process of determining the male
contraceptive PPM in District Cililin were
based on the data of contraception unmet
need resulted from data collection that has
been conducted by the liable officer"
( interviews with informant group 1,
District Cililin, February $11^{\text {th }}, 2016$ ).

PPM calculation process can be clearly understood and has been measured by all family planning managers in these three districts, however, the implementation has not been achievable for vasectomy new-user, particularly in Parongpong. Moreover, the mobilization of vasectomy has its own difficulty compared to condom mobilization. Other challenges in implementing male contraception are human resource and sociocultural.

\section{Resources}

The second variable affecting policy performance is resources. The resource consists of all resources that are usable in supporting the success of policy implementation including human resources, financial resources, and facilities. According to Van Meter van Horn (1974), resource policies have an important role in policy implementation. No matter how clear and consistent the standards and objectives, policy implementation will be ineffective if the policy implementer is lacking in the resource.

Study in Cililin, Batu Jajar, and Parongpong show that a program manager is required to be knowledgeable of the task of embodying the family planning program in Bandung Barat Regency.

\section{The number of family planning manager}

Family planning program revitalization is currently focused on two things: restructuring the family planning program and restructuring the management's human resources. The arrangement of the family 
planning program focuses on free contraception service in the next few years, whereas human resources focus on revitalizing and regenerating the role of family planning counselors.

Considering the decreasing number of family planning counselors in Bandung Barat Regency since decentralization, the family planning counselor regeneration is heavily needed. Decentralization means that family planning counselors are in the authority of the regional government. Hence, if the regional government has not prioritized the needs of the counselor's recruitment, revitalizing family planning in the regions becomes challenging, as it faces the human resources shortage.

The study found that there are only 107 of family planning officers in Bandung Barat Regency compared to the number of villages (165). Hence, each officer has to manage one or two villages while the ideal workload is one manager per officer.

Table 2. The ratio of officer compared to the village in District Cililin, Batu Jajar and Parongpong in 2015.

\begin{tabular}{|l|c|c|c|}
\hline \multicolumn{1}{|c|}{ Districts } & $\begin{array}{c}\text { Number of } \\
\text { villages }\end{array}$ & Number of officers & $\begin{array}{c}\text { The ratio of } \\
\text { officer per } \\
\text { village }\end{array}$ \\
\hline Cililin & 11 & 8 & 1,38 \\
\hline Batu Jajar & 7 & 7 & 1,00 \\
\hline Parongpong & 7 & 7 & 1,00 \\
\hline
\end{tabular}

(Source: Data and Information Office of BKKBN West Java)

Interviews with the key informants show that District Cililin has the smallest ratio of officer per village, while Batujajar and Parongpong has a proportional ratio. Furthermore, the researcher found that only 3 of 8 managers were civil servants, while the remaining 5 were honorary staff working as village motivator.

The village motivator is the driving force of family planning programs and policies based in villages ho have the task of planning, organizing activities, reporting and evaluating family planning programs within the village across in West Java province.

\section{Officer knowledge}

In general, all officers have understood the main task of implementing the male contraception program. However, the civil servant official shows a higher level of knowledge compared to the honorary village motivator. This is because the honorary village motivator has just been launched since 2010. Therefore, the transfer of knowledge is needed between the official and the village motivator, and this could be done by the official acting as a supervisor for the new recruits. Further analysis refers to the excellent knowledge of family planning managers in District Batu Jajar and District Cililin. However, counselor's in Batu Jajar needs to improve their counseling techniques.
Meanwhile, family planning counselors in District Parongpong shows a lower level of knowledge, and therefore, transfer of knowledge is heavily needed.

Furthermore, family planning managers in District Cililin show a remarkable difference, as in general the knowledge between the official were almost equal, especially in understanding the social characteristics of its population. This is because the program managers were locals and live in Cililin. Moreover, the program managers conduct many visits to the residents through family data collection program, counseling and interrelated partnership with a religious figure and public figure.

Study finds that in the three districts, communication has been shown as one of the most important competencies for a family planning manager. This is because a family planning manager has public presentations, as well as doing counseling. Another competency is mastering the material presented in an oral presentation, as well as using the teaching/counseling kits. Moreover, Officer's attitudes in serving their role as a counselor provide supports in performing their duty.

In accordance, Zaeni (2006) found that a low quality in human resources leads to a declining ability in performing male contraception counseling. Moreover, the lack of counseling media for male contraception implicated to the decrease of male contraception participants. In addition, a study by Desmalita (2009) shows that there is a significant relationship between education, knowledge level and wife's role and the male participation in the family planning program.

The study underlined that in District Cililin, although District Cililin achieveed only $42 \%$ of new male contraception in 2015 (21 out of 50 targetted) the achievement is higher compared to another two districts. This achievement has been remarkable during the pro and contra about male contraception. Furthermore, it is shown that individual counseling is the most effective and mostly performed by the family planning manager. This is because individual counseling is deemed to be concise and easier to conducts as the time and place are flexible compared to a mass/ group counseling which more costly and timeconsuming. Knowing the sociocultural characteristics also help the family planning official to adapt and performing counsels.

"in the implementation of counseling, we usually adapted to the environmental background and the characters of the targeted group, including the language style. For example, perfoming counseling in the ojek community required the program managers to follow the language 
of ojek driver. Firstly, the ojek driver needs to accept us, only then we will introduce the family planning program and invite them to join the male contraception program" (interview with informant group 1, Cililin District, February 11th, 2016).

The study found that family planning counselors take every chance they have to perform counseling, for example doing counseling while doing their same hobby such as fishing in a group, as well as entering a gemstone community. Furthermore, key informant reveals that being a role model is a vital requirement. Male contraception counselors need to undergo male contraception so that he could counsel another male to be a male contraception participant. A role model consists of every single aspect regarding words/ speech, actions, attitudes and behavior of someone who can be imitated by another party (Nasriyah. 2016).

\section{Male contraception funding}

Male contraception program in Bandung Barat Regency is funded by three budget sources, including the national health insurance scheme (BPJS kesehatan), state expenditure budget (APBN) through the national population and family planning board (BKKBN representative of Jawa Barat), as well as regional expenditure budget (APBD) through BP3AKB of Bandung Barat Regency.

Initially, the allocation of the family planning funding budget consists of mobilization cost and medical expenses. Since the implementation of the national health insurance scheme in 2014, the cost of medical expenses was included in BPJS kesehatan. Therefore, state expenditure and regional expenditure no longer concludes the medical expenses. According to the circular letter of the head of BKKBN No: 238/KB.103/E1/2014 about Family Planning Service in BPJS era, the exception of funding applies for people who were not yet covered by BPJS kesehatan and under poverty line category.

In vasectomy as a term of male contraception program, the mobilization budgeting consists of counseling expenses for counselors as well as an allowance for three days. This three days allowance is an income replacement because the newly vasectomy participant is required to have a three-day rest.

\section{Family planning facilities}

In addition to the availability of qualified counselors, the availability of service facilities also plays a vital role in supporting the success of implementing a policy.
The following tables show the availability of family planning services in the districts of Cililin, Batu Jajar, and Parongpong.

\section{The characteristics of the family program manager}

The third variable that influences policy performance is the characteristics of the implementing agent which consists of the structure of the bureaucracy, norms as well as the relational pattern of the bureaucracy.

\section{Organizational structure}

As the board managing family planning program in Bandung Barat Regency, BP3AKB is an organization in the form of line organization and staff, led by a head of board, and consist of for major divisions: 1) women's empowerment and child protection; 2) family prosperity; 3) family planning and reproductive health 4) advocacy and information.

The line and staff organization are indeed commonly used by government bureaucratic agencies of a high level of complexity. The overall result of interviews of family planning managers describes that the existing organizational structure is sufficient to accommodate the needs in program management in Bandung Barat regency. However, the factual implementation of the male contraception program requires a room for partnership in the organizational structure. For example, the implementation of a vasectomy requires a medically trained technician. However, organizational structures fail to accommodate this qualification. Therefore the BP3AKB needs to use a partnership with the health department so that they could perform the vasectomy service and reach the target of the male contraception target.

In conclusion, to perform a good male contraception program in Bandung Barang Regency, well program characteristics need to be in line with partnership aspects.

\section{Communication among program administrators, coordination between administrator and interrelated agency}

Referring to the partnership model conducted by $\mathrm{BKKBN}$, the BP3APKB adopted four stages of a partnership. Firstly, coordination in strengthening the commitment to monitor and evaluate. Secondly, integration between population and family planning and other development sectors. Thirdly, synchronization of interrelated sectors and fourthly cross-sectoral collaboration.

To date, the BP3APKB experiencing continues changes and development in terms of partnership models. The BP3APKB is mostly partnered with the health department in the provision of contraception 
services, while in the male contraception's candidates mobilization, the partnership is mostly conducted with the police department, army, as well as the participant of male contraception groups. In addition, the partnership is also carried out in maintaining the participant of contraceptive use (i.e preventing contraceptive use dropped out).

Communication with partners is done through coordination meetings or staff meeting starting from the district level to the RT / RW level which was carried out at least once a month. Besides as an evaluation material it also served as the latest information dissemination and strengthened the commitment of managers and work partners regarding their support for the male family planning program.

"The current coordination process has been carried out quite well. Cross-related sectors such as the TNI, religious leaders, PKK and RSUD are involved. Alhamdulillah, all can actively support and synergize in the effort to mobilize and provide medical services for male KB. (Interviews with the head of the UPT KB in Batu Jajar District; informants Group 1 in Batu Jajar Subdistrict, 11 February $11^{\text {th }}, 2016$ ).

\section{The administrator's disposition}

The study found that enhancing male contraception users has been conducted in accordance with the operational mechanism. Interviews with the program managers further supporting the continuity of the operational mechanism. Hence, the majority of the family planning managers have understood the program and its goals. As previously stated, the clear and measurable goals help the implementation of the male contraception program.

In addition, the family planning managers understood the importance of patience, good behavior, attitudes and familiarity with the people around them, hence they programs that being socialized are easily accepted. Moreover, a well-maintained closeness between the family planning managers combined with the ability to provide quality counseling enhance the acceptability of the counsels.

In association with the sociocultural aspects, it is found that when the family planning managers work in accordance with the local value (i.e involving the religious leader) in District Cililin and District Batu Jajar, the male contraception program is accepted easier compared to in District Parongpong where the religious leader was not involved in the approach.

\section{The socioeconomic and political environment}

\section{Social environment}

Social diversity is one of Indonesian unique, and also one of the West Java characteristics. Jawa Barat is predominantly inhabited by Sundanese ethnic, however, each residential groups has a different sociocultural background. In general, the sociocultural conditions of people in the three districts studied refers to the Sundanese customs and tradition where the philosophy of caring, a foundation of mutual love, as well as sharing of knowledge are highly valued. This Sundanese philosophy contained in the sentence: silih asah, silih asuh, and silih asih, which means the order of life which is reflected in its harmony with nature, the fellow community and the closeness to the God.

According to the head of the BP3APKB of Bandung Barat Regency, the community response to male contraception program is diverse. People acceptance, indifference, and rejection is the result of their cultural understanding. In addition, to date, male contraception is deemed as religiously unlawful by several people. Furthermore, in the majority, contraception use is considered as a women's matter. Therefore, a continuous effort from the family planning managers is still in need, particularly in the involvement of personal and religious approach in the implementation of male contraception policies.

\section{Economic}

The economic variables in this study limited to the data of male contraception participants and their level of economic ability. According to Latifa (2014), the low level of male contraception participant is the result of the low economic capacity. Vasectomy is deemed as expensive, therefore, it is unlikely that low-income families will be involved in the program. However, this study shows a different conclusion. According to the routine statistics of the BKKBN Jawa Barat, it is found that the majority of vasectomy new users in Bandung Barat regency were categorized as lowincome (poor family) (56.9\% of new vasectomy user). The detailed on the data of vasectomy user are as follow.

Table 4. The participant of male contraception according to the economic background in District Cililin, Batu Jajar and Parongpong in 2015 .

\begin{tabular}{|l|c|c|c|c|c|c|}
\hline \multirow{3}{*}{ District } & \multicolumn{2}{|c|}{ Number of new users } & \multicolumn{2}{c|}{ Low income/poor family } & \multicolumn{2}{c|}{$\begin{array}{c}\text { Percentage (\%) of a low- } \\
\text { income family } \square\end{array}$} \\
\cline { 2 - 7 } & Condom & vasectorny & condom & vasectomy & condom & Vasectomy \\
\hline Cililin & 64 & 22 & 64 & 18 & $100 \%$ & $81,8 \%$ \\
\hline Batu Jajar & 57 & 39 & 24 & 0 & $42,1 \%$ & $0,0 \%$ \\
\hline Parongpong & 15 & 0 & 9 & 0 & $60 \%$ & $0,0 \%$ \\
\hline
\end{tabular}

According to table 4, District Cililin shows the highest percentage of new users with low income/poor family (100\% and $81,8 \%$ of condom and vasectomy new users respectively). On the other hand, District Batujajar shows that vasectomy new-user did not come from a low economic background. The effects of economic to 
vasectomy users could not be seen as there is no data on vasectomy new users in Parongpong.

The data further supported by interviews with the key informants. It is stated that the majority of male contraception is influenced by economic background. The key informant confirms that the new vasectomy user from District Cililin generally comes from the low-income family. Furthermore, receiving the living allowance as an income replacement is a vital factor supporting the decision to have a vasectomy.

\section{Politics}

The impacts of political support in policy implementation include the economic resources for policy implementation, the nature of public opinion, as well as the extent of political support provided. The local government of Bandung Barat Regency (Bupati) clearly confirms the vital and remarkable political support. The political supports are shown in the form of:

1. Issuing a recommendation letter such as establishing family planning quality control.

2. Providing honorarium for the male contraception groups (paguyuban KB Pria) per 3 months.

3. Providing grant assistance to the manager of the youth information and counseling center (PIK-R) and the male contraception groups (paguyuban KB Pria).

4. Rewarding partner group by providing motorbike to facilitate mobilization access for remote area.

Interviews with the family planning managers confirm that the political support provided has been a great help for the program implementation.

Mr. Bupati's support has been very good, he is very concerned about the male family planning program. In fact, he provided grant assistance specifically for our family planning programs including assistance for male family planning groups. Honestly, it really motivates our friends in the field. " (Interviews with informant Group 1 at the Kopassus Training Center, March $\left.3^{\text {rd }}, 2016\right)$.

Political support could be implemented in several forms. Several subdistricts in Bandung Barat Regency has provided contraception expenditure in the village allocated budget, that are Desa Saguling, Desa Ngamprah, and Desa Cipongkor, whereas, in other districts, political support could be implemented in the form of role modeling or provision of official statement/regulation.

Based on the study, it is found that the head of District (camat) of District Parongpong and District Batu Jajar providing political support by becoming a role model of the program. Becoming a vasectomy user, the head of districts could drive motivation and simultaneously increase the continuity of advocacy.

\section{CONCLUSION}

Based on the research, it is concluded that the increasing of male contraception policy in districts Cililin, Batu Jajar, and Parongpong is well implemented, therefore, the new-user target is achieved. The influencing factors as follow:

1. The clear and measurable standards and objectives of the male contraception program

2. Involvement of religious leader in personal approach and counseling

3. Well communicated and coordinated program managers

Political support, budgeter provision, and role modeling aspects.

\section{RECOMMENDATION}

Based on the result of the study, the author provides several recommendations as constructive input for developing male contraceptive policies.

1. As the managing board of family planning in Bandung Barat Regency, it is expected that the BP3AKB conducts capacity building for family planning counselors, especially for the village managers, both through training and mentoring processes. Collaboration with $\mathrm{BKKBN}$ in the training process, and mentoring provided by the senior family planning counselors.

2. Collaboration between the BP3AKB and BKKBN in terms of mobilization cost, i.e co-sharing in transportation cost.

3. Family planning managers are expected to actively conduct advocacy to policymakers in the local government level. For example, the local government provides budgeting for a family planning program.

4. Advocacy and collaboration with the religious leader are pivotal in enhancing male contraception. For example, the Muslim Leader fatwa in developing vasectomy new-user. 
5. To consider including the partnership aspects in the BP3AKB organizational structure.

6. Intensification of counseling for middle-class target, especially on the population controlling and gender equality program.

7. Optimizing role modeling and political support as a model for male counseling policies across districts in Jawa Barat Province.

Considering the complexity of socioeconomic and political variables in influencing male contraception, further research examining the issues is need. Moreover, the social challenge related to the religious stand of male contraception, in particular, is a pivotal step as several people considers that the male contraception program as unlawful from a religious understanding.

\section{REFERENCES}

1. Musafaah M. Keikutsertaan Pria dalam Program Keluarga Berencana di Indonesia. Kesmas J Kesehat Masy Nas. 2012;7(4):15861.

2. Ernawati S. Faktor yang Memengaruhi Keluarga Berencana (KB) Pria dengan Paritisipasi Pria dalam Keluarga Berencana di Wilayah Kerja Puskesmas Sedayu II. J Ners dan Kebidanan Indones [Internet]. 2016;4(2):109. Available from: http://ejournal.almaata.ac.id/index.php/JNKI/ar ticle/view/250

3. Desmalita D, Nursal DGA, Suryati S. Beberapa Faktor Yang Berhubungan Dengan Partisipasi Pria Sebagai Peserta KB Di Kelurahan Tembilahan Kota Tahun 2008. J Kesehat Masy Andalas. 2009;3(2):77-81.

4. Kassa M, Abajobir AA, Gedefaw M. Level of male involvement and associated factors in family planning services utilization among married men in Debremarkos tow .... Level of male involvement and associated factors in family planning services utilization among married men in Debremarkos to. 2014;(December):1-8.

5. Latifa S, Suhasti E. Partisipasi suami melakukan vasektomi. Fak Syari'ah dan Huk UIN Sunan. 2014;7(2):121-34.

6. Muhatiah R. Partisipasi Pria Dalam Program Keluarga Berencana ( KB ). Dinas Kesehat
Kabupaten Kampar.

7. Anggy Dwi Putriandani. Persepsi Akseptor KB MOP dalam Pelaksanaan Program KB di Kecamatan Gayamsari Kota Semarang. UNDIP Semarang. 2015;2501011114:2015.

8. Taufik M, Salawati T, Kesehatan F, Universitas M, Semarang M, Subur PU. DI KABUPATEN DEMAK ( Studi Pada Masyarakat Pesisir Dan Masyarakat Kota di Kabupaten Demak ) PUBLIC PERCEPTION OF MEN KB IN DEMAK ( Studies in Society and Society of Coastal Cities in Demak ) Program Keluarga Berencana di Berdasarkan data Badan Pusat Desa . 2015;10(2):35-44.

9. Ragil Wiwik Setyaningsih. Hubungan Persepsi Tentang Kehidupan Rumah Tangga dengan Keikutsertaan Vasektomi. UNDIP Semarang. 2007;50:3-4.

10. Zaeni A. Implementasi Kebijakan Program Keluarga Berencana di Kabupaten Batang Studi Kasus Peningkatan Kesertaan KB Pria di Kecamatan Gringsing. Progr Pascasarj Univ Diponegoro. 2006;

11. NYISOS.GIT WUDI AMINI S. Implementasi Kebijakan Program Kb Pria (Studi Kasus Tingginya Pencapaian Mop Di Kabupaten Situbondo Provinsi Jawa Timur). 2011; Available from: http://etd.repository.ugm.ac.id/index.php?mod $=$ penelitian_detail\&sub=PenelitianDetail\&act $=$ view\&typ $=$ html\&buku_id $=51241$

12. Horn CEVAN. Administration \& Society. 1975;

13. Nasriyah. Pentingnya Keteladanan Seorang Pendidik [Internet]. 2016. Available from: http://bontang.prokal.co/read/news/3907pentingnya-keteladanan-seorang-pendidik.html

14. BKKBN Kalbar. (2016). Mengapa Harus Bermitra?. Diakses dari: http://kalbar.bkkbn.go.id

15. Creswel, John.W. (2009). Research Design: Pendekatan Kualitatif Kuantitatif, dan Mixed.Yogyakarta: Pustaka Pelajar. 